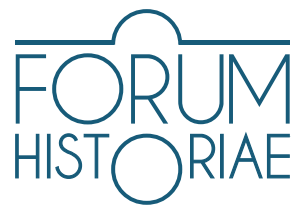

\title{
Self-publishing and Building Glocal Scenes: Between State Socialism and Neoliberal Capitalism
}

\author{
Karel Šima - Miroslav Michela
}

\begin{abstract}
ŠIMA, Karel - MICHELA, Miroslav: Self-publishing and Building Glocal Scenes: Between State Socialism and Neoliberal Capitalism.

In this article we introduce the theme of special issue focusing on sel-publishing activities In Central and Easter Europe from 1980s to 2000s. The articles presented in this issue offer an interdisciplinary view on the history of independent publishing in both the late socialist and post-socialist periods. We would like to enrich the scholarly debate beyond the dichotomies of communism/capitalism, socialism/post-socialism, East/West and samizdat/fanzine, respectively. Different variants of do-it-yourself cultural creativity highlight the space that lies between the established high-brow and popular low-brow cultures. Specifically, the intersections between the approaches of art history, musicology, cultural studies, sociology, literary history, and media studies constitute a representative spectrum for these reconciliations. We would like to highlight the observation of all our contributors that self-published press and books bring a specific value to the building of communities or scenes that are not only locally embedded, but also interlinked globally, and show how various cultural trends were established and developed in different sociocultural and national settings. They bring so-called hidden voices to the forefront, which allows the building of one's own creative space for different kind of activities with significant value also in our post-digital era. Our cases show that the socialist and post-socialist contexts enabled interesting shifts in the economic and social positioning of self-publishing activities. In this respect, we would see the most interesting cases for further research in situations when different agents from different parts of the cultural field meet together, connect different audiences, and foster new ways of creativity that can transgress the logic of late capitalism.
\end{abstract}

Keywords: Central and Eastern Europe; fanzines; samizdat; self-publishing; alternative press; scenes; socialism; post-socialism

DOI: https://doi.org/10.31577/forhist.2020.14.2.1

$I^{n}$

n our special issue we would like to open the debate about the different contexts where we can find self-publishing and alternative publication strategies intended to build or maintain various scenes in Central and Eastern Europe (CEE). Compared to the previous issue of Forum Historiae, which was dedicated to subcultural zines, we opened the discussion for a wider spectrum of independent publishing which played a specific role in socialist and post-socialist societies. Stepping out of the narrow boundaries of subcultures and their fanzines, we would like to reflect on alternative publishing in a much broader sense of different kinds of zines, literature and art books, produced mostly in small print runs for insiders and supporters. 
The articles presented in this special issue offer an interdisciplinary view on the history of independent publishing activities both in the late socialism and post-socialism periods. They cover the period from the 1970s to the 2000s, inviting readers to think about the topic beyond the dichotomies of communist/ capitalist regimes, socialism/post-socialism, East/West and samizdat/fanzine, respectively. The contributions allow the intersections between different disciplinary discourses that challenge the relation between genuine artistic creation and mainstream cultural complex to be seen. Different variants of do-it-yourself cultural creativity highlight the space that lies between the established high-brow and popular low-brow cultures. Specifically, the intersections between the approaches of art history, musicology, cultural studies, sociology, literary history, and media studies constitute a representative spectrum for these reconciliations.

Self-publishing is often recognized as an oppositional activity - to oppressive state socialist regimes or a savage capitalist state - but it does not answer the question of why such practices persisted and even flourished in post-socialist societies. Regarding the regional context of $\mathrm{CEE},{ }^{1}$ we would like to address the questions: What are the limits of post-socialist research on pre-1989 self-publishing? How can we go beyond understanding it solely as an oppositional press to state socialist regimes?

In this sense we would like to highlight the observation of all our contributors: that self-published press and books bring a specific value to building communities or scenes that are not only locally embedded, but also interlinked globally. They help to share information, alternative cultural narratives and joy. They bring so-called hidden voices to the forefront, which allows them to build their own creative space for different kinds of activities, mostly connected with music, art, literature, or beliefs. They establish cultural and personal networks and interconnections with the world beyond regional or state borders. Alternative media can help build collective identities and at the same inform them about similar symbols, ideologies, values etc. in the global context. In CEE our studies show that even if the Iron Curtain represented a significant barrier to the global circulation of cultural material, at least in some cases the transnational and East/West information channels were essential for the local cultural spaces and led to similar cultural practices on both sides of the Iron Curtain.

Our aim in this special issue is to show how various alternative cultural trends were established and developed in different socio-cultural and national settings. In doing so, we would like to contribute to debates over the relationship between the local and the global in contemporary history. Ewa Mazierska proposes that scholars should focus more on "participation", that is, they should consider the popular music of CEE as an "articulation of local culture and an act of participation in the global phenomenon of popular music." "Imperialist" Anglo-Ameri-

1 We have included the article by Alexandra Karamoutsiou, even though it does not fit in geopolitical space of CEE and state socialism. However, we observe interesting comparative dimensions that enable the comparison of Greek subcultures with CEE, especially because they were also perceived as a part of "the other" Europe.

2 MAZIERSKA Ewa. Introduction. In MAZIERSKA Ewa (ed.) Popular Music in Eastern Europe. Breaking 
can pop-rock music was adapted to meet local needs and sensibilities, as well as dynamic global trends. By shifting the focus, a space emerges in which the relationship between the post-colonial and the post-socialist can be debated. ${ }^{3}$ Hence, we need to study self-publishing as a "glocal" phenomenon. Motti Regev argues that "in late modernity, we have to treat world culture as one complexly interconnected entity, in which social groupings of all types around the globe growingly share wide common grounds in their aesthetic perceptions, expressive forms, and cultural practices."

Finally, we would like to point out in this introduction that independent publishing has principal value in our post-digital era, too. In our late capitalist context, when we are increasingly overwhelmed by digital content, more and more creators are turning back to printed publications as material objects full of emotional, embodied experience that enable people to relate to others through extended physical contact. This trend is also moving the interest in independent publishing towards the artistic expression of individual and collective creativity.

\section{Self-publishing and alternative press}

In this thematic issue, we would like to offer a broad conceptual framework of alternative and self-publishing strategies in the second half of the $20^{\text {th }}$ century and the beginning of the $21^{\text {st }}$ century. The authors of the articles primarily discuss the creators' motivations and production strategies, and they reflect on the technological and socio-political changes that have affected self-publishing, where economic benefit is not the main activity driver. Based on this observation we would like to introduce here two concepts that reflect on these characteristics, even if they cover empirical material narrower than the case studies in our issue.

According to the seminal work of Chris Atton and James F. Hamilton, alternative journalism proceeds from dissatisfaction not only with the mainstream coverage of certain issues and topics but also with the epistemology of the news, and it can include the media of protest groups, dissidents, fringe political organizations, or even fans and hobbyists. ${ }^{5}$ Alternative media also pose challenges to the dominant representational practices of mainstream news. They offer a remarkable critique through activities that may be part of a broader self-reflection of contemporary academia and society. Alternative journalism suggests that authority does not need to be located institutionally or professionally; that credibility and trustworthiness can be derived from accounts of lived experience not only from objectively detached reporting; and that perhaps there is no need to separate facts from values. ${ }^{6}$ In all the case studies in this special issue this affectual relationship towards the values of the scenes represents a crucial motivation for self-publishing.

\footnotetext{
the Cold War Paradigm. London : Palgrave, 2016, p. 4.

3 OWCZARZAK, Jill. Introduction: Postcolonial Studies and Postsocialism in Eastern Europe. In Focaal, 2009, Vol. 53, No. 3, p. 3-5.

4 REGEVS, Motti. Pop-rock Music: Aesthetic Cosmopolitanism in Late Modernity. Cambridge : Polity Press, 2013, quoted in MAZIERSKA 2016, p. 5.

5 ATTON, Chris - HAMILTON, Jeff. Alternative Journalism. London : SAGE, 2008, p. 1.

6 ATTON, Chris. Why Alternative Journalism Matters. Journalism, 2009, Vol. 10, No. 3, p. 283-285.
} 


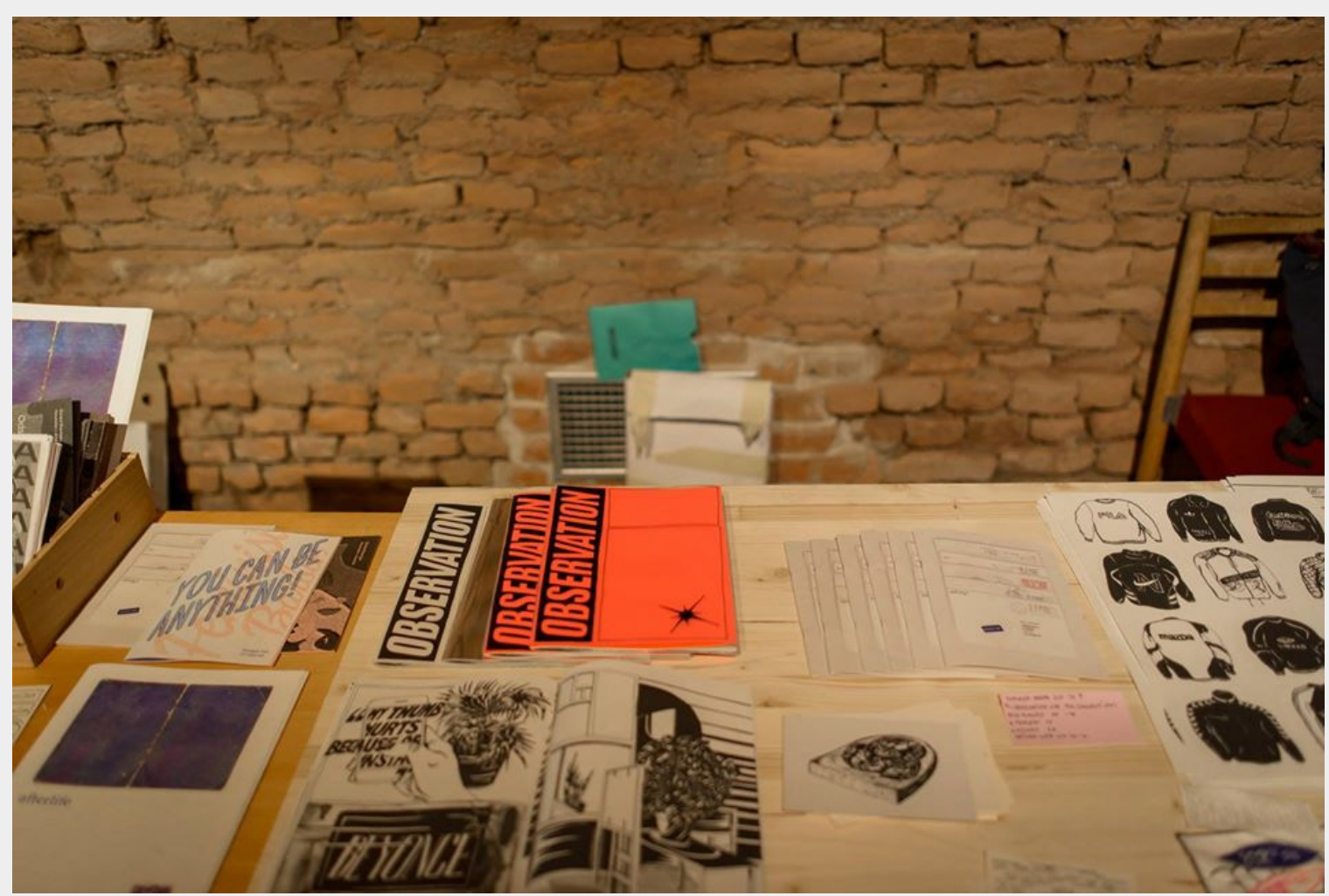

Figure 1. Fanzines for sale at zine fest organized in creative centre Kubik in Trnava, Slovakia. Source: Peter Lančarič/Kubik.

In research on CEE history and in public debate, the role of alternative media and self-publishing has been basically overlooked by academia, with the exception of samizdat, which is presented as an important part of dissent heritage. There are probably several reasons why this is so, but we can generally observe a certain blindness to these historical sources because they are perceived as marginal activities with limited circulation and a negligible impact on general historical trends, i.e. the "Great Narratives" of the Iron Curtain and its fall. Even research on samizdat, whose role in the struggles against communist regimes was acknowledged as early as in the 1990s, did not develop significantly among academic scholars until the 2010s. However, in recent the alternative media - whether identified as "grassroots," "independent," "community," "participatory," "self-managed," "autonomous," "tactical," or "alternative" - has moved from the margins of political and academic debate to the centre. The emergence of the Internet in the late 1990s and new digital communication platforms in the 2000s played an important role in gaining alternative media more serious recognition, as they opened up new opportunities for self-expression and community building. In this respect the Internet started a new era of digital activism. ${ }^{7}$ However, alternative or non-institutionalized media channels have also enabled the expansive spreading of fake news and conspiracy theories in recent years.

Olga Baily et al. suggest that "alternative media are articulated in many different ways - not only in relation to the mainstream media, but also as community media,

7 PAJNIK, Mojca - DOWNING, John. Introduction: The Challenges of "Nano-media”. In PAJNIK, Mojca DOWNING, John (eds.). Alternative Media and the Politics of Resistance: Perspectives and Challenges. Ljubljana : Mirovni Inštitut, 2008, p. 7-9. 
as civil society media, and as rhizomatic media". 8 The concept of the rhizome is associated with the work of Gilles Deleuze and Félix Guattari, who suggest that rhizomes are a useful metaphor for the "juxtaposition of rhizomatic and arbolic thinking." Underpinning alternative, collaborative, and community media, then, are links with civil society that form intersection points with other structures. So, rather than viewing community media and alternative media as fixed, it becomes possible to see these as "organizational structures where alternative media organisations can remain grounded in local communities and become simultaneously engaged in translocal networks." These translocal networks are fluid and diverse and have been established so that they avoid the "dichotomised positioning of alternative media in relationship to the local and the global," or the market and the progressive, or the consumer and the producer. Thus, the rhizome highlights a different way of speculating about how the "local and global touch and strengthen each other within alternative media".9

As was mentioned by Miloš Hroch, even if the Internet dominates the communication in alternative scenes today, there are still activists who have not abandoned the publication of paper zines. ${ }^{10}$ In recent years we can see a clear trend towards a zine revival. ${ }^{11}$ The idea of self-publishing is promoted at book markets and zinefests full of various kinds of art books and zines. On one hand, the medium of the zine has become a form of artistic expression presented both in galleries and independent press markets. On the other hand, alternative scenes still have a demand for personal contact through self-published material, and the experience embodied by creating and sharing paper publications seems to be even more attractive in the post-digital era than before. There are even some significant changes in releases, content, and layout in comparison to the 1980s - 1990s. Our impression tells us that physical contact via self-published books and magazines still enables the creating and cultivating of an independent space for scenes today and is still an important part of subcultural and alternative way of life. ${ }^{12}$

\section{Scenes}

Self-published media, as shown in this special issue, were an important mediator within varied communities. There is also a diverse level of theorization of the communities involved in different disciplinary contexts, but the conceptual debate has been well developed, first of all within subcultural studies. The concept of a subculture as the main denominator of the alternative communities was already being criticized in the 1990s, when the concept of the scene became very

8 BAILEY, Olga - CAMMAERTS, Bart - CARPENTER, Nico. Understanding Alternative Media. Maidenhead : Oxford University Press, 2008, p. xii.

9 BAILEY - CAMMAERTS - CARPENTER 2008, p. 27.

10 HROCH, Miloš. Zprávy z první linie. Proměny hardcore-punkových fanzinů v postdigitální době. In Český lid, 2019, Vol. 106, No. 1, pp. 29-47.

11 We have lived through a pandemic during the preparation of this special issue, which seems to force an opposite trend-towards complete digitisation of communication. We think that this trend could paradoxically make the demand for authentic and self-published print media that contain personal footprints even stronger.

12 KUŘÍK, Bob - SLAČÁLEK, Ondřej - CHARVÁT, Jan. Úvod: mládež, hudba, politika. Jak zkoumáme politizaci subkulturních scén? In CHARVÁT, Jan - KUŘÍK, Bob et al. Mikrofon je naše bomba. Politika a hudební subkultury mládeže v postsocialistickém Česku. Prague : Togga, 2018, s. 33. 


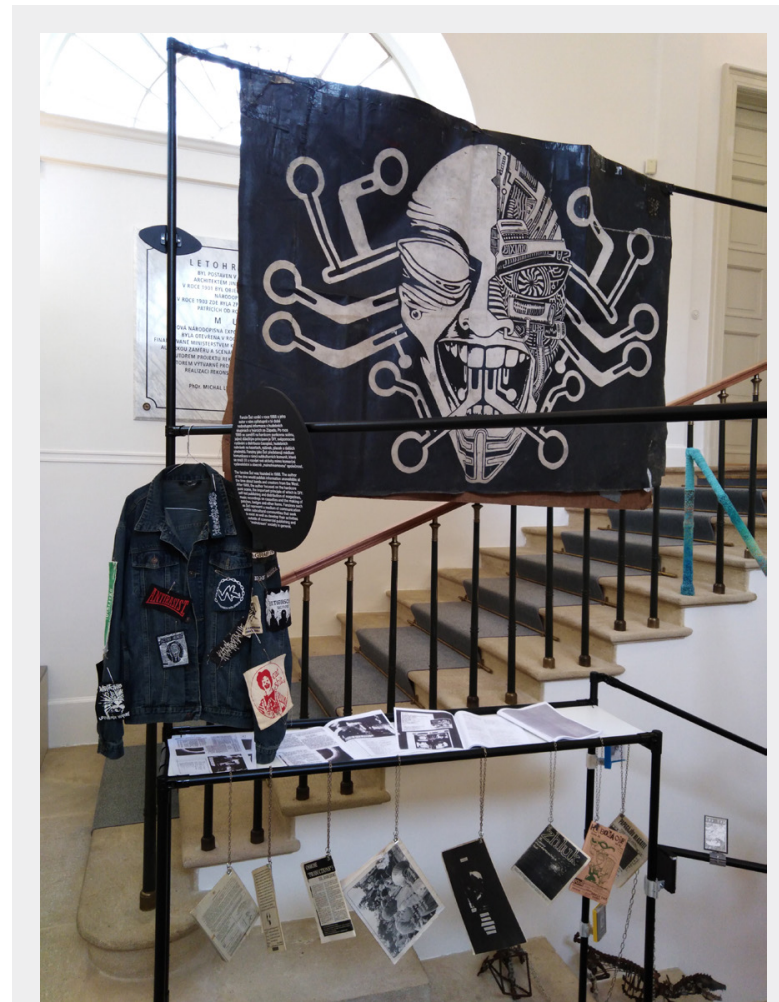

Figure 2. Picture taken on the recent exhibition of Ethnographic Museum of the National Museum in Prague, Czech Republic, dedicated to different faces of the Do It Yourself phenomenon. Source: Miroslav Michela. widely used in popular music studies and was presented as a superior alternative to "subculture". It highlighted a contrast between local participatory practices and the dominant or mainstream culture. In the words of Barry Shank: "spectators become fans, fans become musicians, musicians are always already fans" and they create a productive environment for they activities. A scene itself was defined as an over-productive signifying community. ${ }^{13}$

In this respect - as noted by Will Straw - scenes can be both local and translocal, because they can designate both "face-to-face sociability and a lazy synonym for globalized virtual communities of taste".14 This ambivalent spatial notion of a scene was stressed by Keith Kahn-Harris, who published his ethnography of the ex-

treme metal scene in 2007. In his study he viewed metal fanzines as initiators of both local and global communication about the music: "Fanzines were a crucial institution of the scene. As a medium of communication, fanzines produce a kind of dialogic intimacy between reader and writer, which facilitates the formation of the scene as an 'imagined community'."15

In the 2000s the debate around the post-subcultural turn in cultural studies brought several other concepts, which were sometimes presented as competing with one another. Within the Scenes, Subcultures and Tribes: Youth Cultures in the 21st Century conference held in 2003 in Northampton, UK, the advantages and disadvantages of these concepts were debated. ${ }^{16}$ David Hesmodalgh summarized the key criticism of these concepts, ${ }^{17}$ arguing that subculture, scene, and tribe were developed as concepts analysing the relationship between youth and popular music, which is just a specific case coming from specific historical circumstances. In this introduction we do not have the ambition to contribute to this debate with a novel interpretation, and we would rather stick to the moderate

13 SHANK, Barry. Dissonant Identities: The Rock ' $n$ ' Roll Scene in Austin, Texas. Hanover : Wesleyan University Press, 1994, p. 131.

14 STRAW, Will. Scenes and Sensibilities. In Public, 2002, No 22/23, p. 245-257 and 248.

15 KAHN-HARRIS, Keith. Extreme Metal: Music and Culture on the Edge. Oxford; New York : Berg, 2006, p. 86.

16 See KOZOROG, Miha - STANOJEVIĆ, Dragan. Towards a definition of the concept of scene: Communicating on the basis of things that matter. In Sociologija, 2013, Vol. 55, No. 3, pp. 353-374. The conference book appeared four years later HODKINSON, Paul - DEICKE, Wolfgang (eds.) Youth Cultures: Scenes, Subcultures and Tribes. New York and London: Routledge, 2007.

17 HESMONDHALGH, David. Subcultures, Scenes or Tribes? None of the Above. In Journal of Youth Studies, 2005, Vol. 8, No. 1, pp. 28-29. 
position that each of these concepts can be productively used for analysis, depending on the context of the empirical case.

In this respect, these concepts can be seen as more complementary than competing. Even if some of the authors presented in this issue use subcultures as the framework of their analysis, others have very diverse notions of the community that surrounded the self-published publications. However, in our view all of them relate the local and trans-local contexts of publishing activities and thus invite us to see them as scenes in broader terms. The classic combination of subcultural style and rock music is the subject of the analysis of Alexandra Karamoutsiou, who discusses the connection between a local fanzine from Thessaloniki and the music and cultural scene. Similarly, Janis Daugavietis focuses on the local scene in the Russian speaking underground community in late Soviet Riga. Jan Blüml also analyses local rock music fan clubs - in Brno in 1980s - but with a global popular music context. He shows how the music fandom of the Beatles and Frank Zappa were localized in this late socialist regional centre. Mahulena Kopecká takes the case of the classic feminist subcultural style of riot grrrls and asks how the role and characteristics of the fanzine changed within local anarcho-feminist scene in Czech Republic around the transformation from a paper medium to an online digital medium. Martin Tharp focuses his analysis on the specific place that offered new possibilities in publishing print media right after the fall of the communist regime in Czechoslovakia. Petra Loučová's case highlights the efforts to build a scene of supporters of independent book publishing in the same decade, and Kristin Watterott's artists' community can also be viewed as a local scene with a connection (or at least an ambition) to the global context of the contemporary art world.

\section{Case Studies}

Art historian Kristin Watterott examines in her article the unrecognized double function of Czech surrealist samizdats, both as an archiving technique and as independent artistic projects. By the selection, compilation, and presentation of the works, the self-published projects appear as a self-archiving medium adopted by the artistic community. The strategy of archiving is shown in this context as a process that creates its own realities through self-reflection. Nevertheless, the catalogue shows itself to be the result of collective action, the result of joint reflection, action, and creation. In the 1980s, when there was no public reception of collective surrealist creation in museums, institutions, and the scientific community, the group itself provides a remedy by presenting and reappraising its own view of Czech surrealism and group history.

Musicologist Jan Blüml discusses the reception of two of the most influential representatives of Anglo-American popular music in Communist Czechoslovakia, the Beatles and Frank Zappa. The reception of both musical stars is analysed in the specific space of the Brno scene of the 1980s, within the framework of fan clubs and their periodicals, which had no parallel anywhere else in the country. The study demonstrates the specifics of American and British rock fandom du- 
ring state socialism and challenges the long-held narrative about the supremacy of the political functions of rock behind the Iron Curtain.

Music historian Alexandra Karamoutsiou focuses on Thessaloniki's emblematic fanzine Rollin Under, which was active from 1985 to 1992, and describes the relationship between the fanzine, the Thessaloniki music scene, the DIY ethos, and Greece's historical and political context of that time. She describes fanzines as alternative cultural spaces through which music historians can find the untold stories of the participants of the music scenes. She argues that zines could help to clarify the vague traces that DIY scenes left behind, reveal histories that otherwise would possibly remain hidden and untold, and, most importantly, give us the opportunity to listen to the protagonists' voices and their historical narrations as they wrote them at the time. Hence, Rollin Under and similar zines in general should not be considered merely as invaluable primary data but also as alternative cultural spaces that thrive in the ruptures of the global capitalist complex and can offer "a silent revolution" against it.

In his case study on the Om Винma (Ot Vinta) periodical from Soviet Latvia, cultural sociologist Jānis Daugavietis addresses the question of how Western fanzines and music samizdat in the East can be analysed in relation to one another. Thus far, they have been regarded as separate phenomena, but do these two forms of underground literature differ so greatly that they should be analysed using different theoretical approaches? The case examined in the paper is a Russian-language music samizdat published in 1987 - 1991 in the Latvian Soviet Socialist Republic. The paper explores the history of Ot Vinta as a central magazine of the local underground and semi-official rock music scene, tightly interconnected with the unofficial rock music scene of the whole country. Daugavietis argues that there are no significant differences between Soviet music samizdat and Western zines, though there are, of course, differences in design determined by the different means of production and reproduction. There were also differences in the attitude of the state towards zines and samizdat, but the role of music samizdat within the political resistance, which until recently was the dominant thesis in samizdat research, must be questioned.

Historical sociologist Martin Tharp takes a relatively unconventional angle for his investigation of the abrupt shift in Czech unofficial journalistic culture from severely repressed samizdat before November 1989 to a significant social force in the first years of the subsequent decade. It takes as its locus the Prague office building at the address Bolzanova 7, a former Czech Rail property assigned to the samizdat-based independent journalistic agency Informační servis at the end of 1990. Here, in the hectic early years of uncensored publication, the rapid diversification of Czech independent periodicals witnessed the emergence of both culturally prestigious publishing projects (the weekly magazine Respekt, the quarterly cultural journal Revolver Revue) and attempts to reformulate the counterculture under radically different conditions (the transformation of the underground samizdat journal Voknoviny into the cultural bulletin Kontra and subsequently into 
the anarchist periodical A-Kontra). The post-Velvet Revolution era brought an impulse for new movements to emerge, among them new subculture fanzines.

From the perspective of the history of literature publishing, Petra Loučová introduces the "mission" of the Club of Liberated Samizdat on the Czechoslovak post-revolutionary book market, which began being promoted just a few month after the famous editorial of Václav Havel, titled "Goodbye samizdat", in the final issue of the clandestine Lidové noviny from December 1989, that embraced the new publishing possibilities for all. The idea of a "return to samizdat", organized by former samizdat producers, was based on self-publishing practices as a revolt against the principles of market economics in the era of liberalization and transformation. Solidarity and a shared enthusiasm were to motivate people to participate in the running of this "parallel" literary institution without any remuneration. However, these activities were not shown to be sustainable in the long run. Nowadays, we can follow very similar activities in fanzine and art production, often based on crowdfunding or pre-orders.

Mahulena Kopecká presents in her detailed analysis, based in media studies, the transformation of the Czech anarcho-feminist zine Bloody Mary under the impact of the Internet, blogging, and computer graphics software used in the production of the zine in the 2000s. She explores several analytical categories regarding content, form, and readers' reception of the fanzine to determine the impact of personal computers and the Internet on the changes in its existence. In this sense, the influence of the Internet could be traced in the use of sources of information, in the zine's format, and in the relation to anarchist and feminist groups abroad. However, other categories were not influenced by the Internet to such a great extent, partly owing to the authors' stable attitudes towards feminism, their viewing of queer topics, or by their material surroundings. She interestingly documents the changing practices of zine making during the digitization era: from classic riot grrrl cut-and-paste fanzine to a web-based blog and to an attempt to return to the cut-and-paste format that finally led to the end of this fanzine.

\section{Conclusions}

When thinking about the intersections between the particular case studies, we would like to finally confront them with the conceptual scheme developed by Sheila Liming based on Pierre Bourdieau's famous analysis of the literary field. Bourdieu saw that to understand a work of art, we must look not only at the piece of art itself, but rather at the conditions of its production and reception, the specific logic characterising the field of cultural production, and the way in which that field relates to the wider fields of power and class relations. He argued that the field of cultural production is cut through by two opposing principles of hierarchization; the autonomous and heteronomous principles, i.e. the degree of independence from the financial imperatives of the economic sphere, and the degree of consecration differentiating between the limited, closed audiences and the mass audience. Sheila Liming, inspired by Bourdieau's work, proposed a revised 
version of his scheme, ${ }^{18}$ in which zines are shown in the context of print media and in relationship to comparable new media forms (blogs, both those used for political/argumentative or informational purposes, and "personal" blogs, often attached to social networking sites). She pointed out that although zines present a revolt and give space to marginalized voices, they are embedded in the dominant middle class milieu (see the figure 3), because their creators benefit from privileged access to information and technologies, usually have relatively high social and cultural capital, and have high cultural and social competences and entrepreneurship.

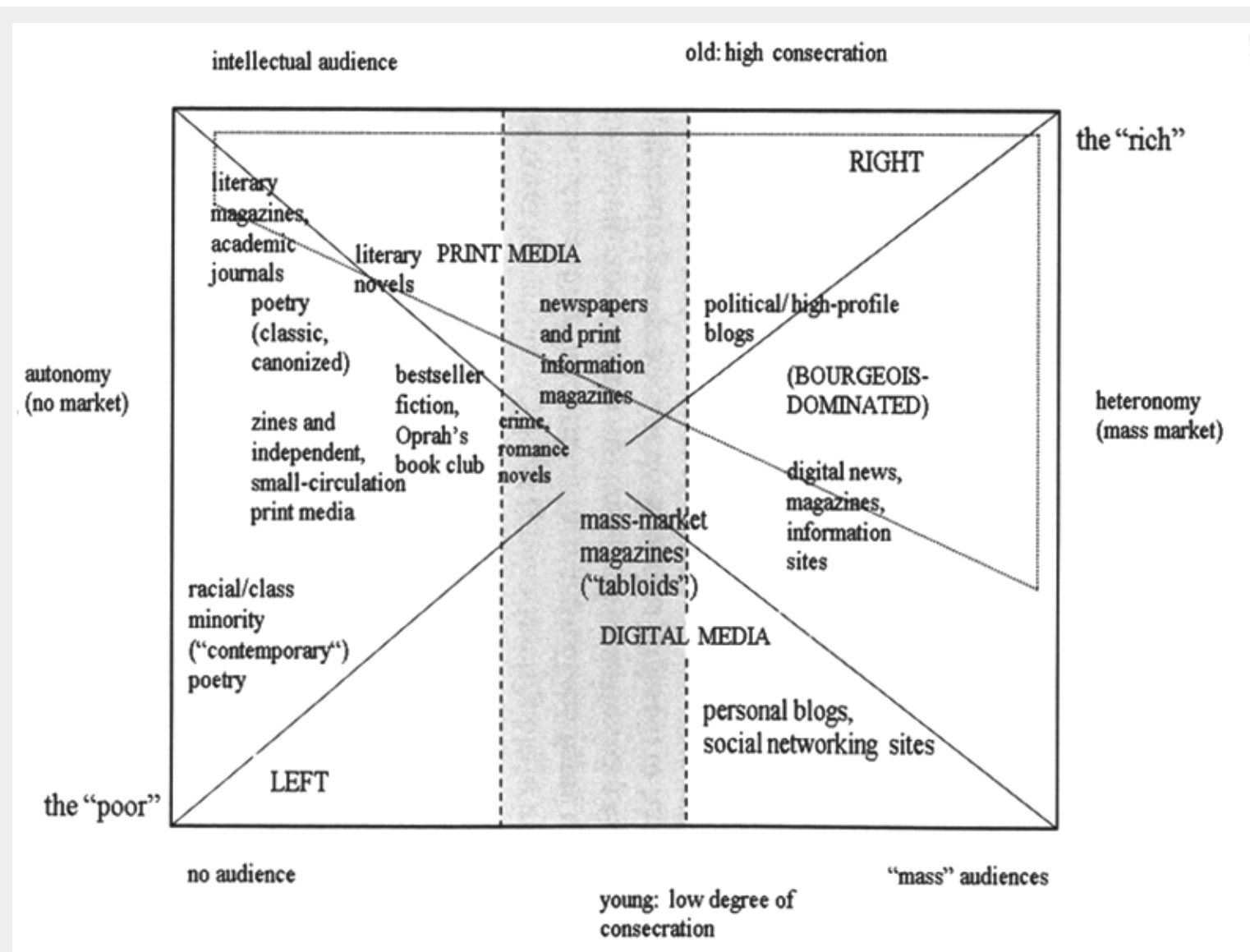

Figure 3. Revised literary field prepared by Sheila Liming. Source: LIMING 2010, p. 133.

In our cases of self-published media, we can locate even more positions within the diagram. Watterott's surrealist samizdats are clearly in the left upper corner, being completely out of the market and with limited intellectual audience. Blüml identifies the borderline between the Beatles and Frank Zappa fan clubs and fanzines that could be placed in the opposite corners of the diagram, and their juxtaposition is possible because of the specific historical circumstances of the late socialist regime. Karamoutsiou analyses in her study a classic subcultural milieu with high value for autonomy (left side) and a moderate level of consecration and class position. Similarly, Daugavietis takes the case of independent, small

18 LIMING, Sheila. Of Anarchy and Amateurism: Zine Publication and Print Dissent. In The Journal of the Midwest Modern Language Association, 2010, Vol. 43, No. 2, p. 121-145. 
circulation print-media which corresponds to the position of zines in Liming's diagram. Interestingly, Tharp shows the climax of the changes of the political and economic regime, when actors and media from different parts of the diagram could meet literally in the same building. Reflecting on the later post-socialist situation of the Czech book sector, Loučová demonstrates how the attempt to connect high quality literary production (upper part) with an interested but numerous audience failed to justify its position in the middle of the diagram. Last but not least, Kopecká clearly shows what is changing when moving from the classic zine (middle left) to the digital magazine (middle right).

To sum up, our cases show that the socialist and post-socialist contexts enabled interesting shifts in the economic and social positioning of self-publishing activities. In this respect, we would see the most interesting cases for further research in situations when different agents from different parts of the cultural field meet together, connect different audiences, and foster new ways of creativity that can transgress the logic of late capitalism.

Writing the history of alternative culture is not just capturing stories of groups and activities that were overlooked by the mainstream culture. It is also important in terms of understanding the critique of the dominant way of life and reflecting on what is considered to be the majority. Self-published publications provide primarily information about what was happening in relatively smaller communities, subcultures, and scenes, but they also open up issues that in many cases sooner or later became important challenges for society at large. For example, in the 1980s and 1990s, very pressing topics of today - environmental protection and climate change - appeared and were debated on the pages of self-published zines. Activism in the alternative culture and non-profit sector introduced in the Czech Republic in 2000s the third wave of feminism that has only hit the mainstream cultural industry in recent years. ${ }^{19}$

The strategies used by the self-publishers to deal with the hegemony of the Communist Party or the market can set up a "crooked mirror" for the dominant discourses and power relations of the time period. The transition from state socialism to post-socialism meant not only significant economic and political changes, but also a rapid transformation of what was understood as the cultural mainstream. From the imaginary West, as designated by Alexey Yurchak, the West became overrepresented in mainstream media and at the same time adored as a utopian model for a transformation of the society. ${ }^{20}$ Contemporary witnesses often reflect on this period as a short epoch, when "everything was possible" and

19 HAŠKOVÁ, Hana - KŘíŽKOVÁ, Alena. Rozhodčí a hráči: Vliv socio-ekonomické transformace a evropské integrace na ženské občanské skupiny. In HAŠKOVÁ, Hana - KŘížKOVÁ, Alena - LINKOVÁ, Marcela (eds.) Mnohohlasem. Vyjednávání ženských prostorů po roce 1989. Praha : Sociologický ústav AV ČR, 2006, pp. 84-87. See also: ROBINSON, Lucy. Zines and history : zines as history. In SUBCULTURES NETWORK (eds) Ripped, Torn and Cut: Pop, Politics and Punk Fanzines from 1976. Manchester : Manchester University Press, 2018, p. 39-54.

20 YURCHAK, Alexei. Everything Was Forever, Until It Was No More: The Last Soviet Generation. Princeton : Princeton University Press, 2005, p. 170-175. 
the borders of the mainstream could expand relatively freely within the general enthusiasm of the new era.

Although research on subcultures and self-publishing is gradually getting underway in CEE, there is a lack of institutional structures that would support it. There are no academic or research organizations profiled in this field of research; financial support is limited, and public, state-sponsored organizations have little interest in this field. The historical sources analysed in this issue are usually not available in official archives and libraries but are held by private collectors or independent organisations. In countries like Germany, France, Great Britain, or the United States of America systematic and long-term run institutional platforms for archiving and processing these sources are relatively well established. We also have some recent successful examples in CEE dealing primarily with samizdat literature and independent art production from the state socialist era. Just to mention a few: the library of samizdat and exile literature Libri Prohibiti in Prague, Fundacja Ośrodka KARTA in Warsaw, or the Artpool Art Research Center in Budapest, where fanzines - even from post-communist era - are also available. ${ }^{21}$

The independent archival project, in which we both participate - the Czech and Slovak subcultural archive - showed us that this type of work has important differences as compared to classical archival approaches. Even if the self-published media are public materials, they do not come from either the public or commercial institutional context. In some cases their creators openly criticize the state and market institutions and see the struggle against them as part of their agenda. This is, of course, a major obstacle for public archives to obtain such material, so we think that independent platforms are more appropriate for collecting and archiving these media.

The magazines we work with still have significance in the subcultural environment, even after a significant shift to Internet communication in the 2000s. Independent press activities have always provided and provide still today space for the transformation of identities and the development of "frontier" discourses that transgress the current perception of "the normal" in society. Still today, it is very tempting to erase the strictly divided roles between producer and consumer.

In conclusion, we would like to point out that most of the research on samizdat or fanzine culture is conducted by people who actively participated in these activities and communities, which brings up important methodological and ethical issues. In this respect, the reflexivity of one's own research position becomes an important issue. We, scholars in this field, should clearly define our position in relation to the researched activities and community, and self-reflexivity should be an explicit part of the research and analysis of the sources. We think that this

21 For more institutions and collections dealing with cultural opposition in the period of state socialism in CEE, see: http://cultural-opposition.eu/registry/. 
moment can bring new impulses to recent debates about the canonization of memorial discourses, such as the anti-communist narratives of "totalitarian regimes" that present bipolar schemes of the fight of "good" against "evil".

\section{Cite:}

Šima, Karel - Michela, Miroslav. Self-publishing and Building Glocal Scenes: Between State Socialism and Neoliberal Capitalism. In Forum Historiae, 2020, Vol. 14, No. 2, s. 1-13. ISSN 1337-6861. DOI: https://doi.org/10.31577/forhist.2020.14.2.1

Mgr. Miroslav Michela, Ph.D.

Oddelenie novších dejín

Historický ústav SAV

P.O. BOX 198

Klemensova 19, 81499 Bratislava,

Slovenská republika

E-mail: Miroslav.Michela@savba.sk
Mgr. Karel Šima, Ph.D.

Ústav hospodářských a sociálních dějin, Filozofická fakulta

Univerzita Karlova

nám. Jana Palacha 2, 11638 Praha 1,

Česká republika

E-mail: karel.sima@ff.cuni.cz 